\title{
Performance of Rice Straw Management and Nitrogen Scheduling on Yield and Growth Parameters of Summer Rice in Chhattisgarh Plain
}

\author{
G.P. Banjara*, D.K. Chandrakar and Birendra Tigga \\ Department of Agronomy, Indira Gandhi Krishi Vishwavidyalaya, \\ Raipur(Chhattisgarh), India \\ *Corresponding author
}

\begin{tabular}{|c|}
\hline Keywords \\
\hline $\begin{array}{l}\text { Rice straw } \\
\text { management, } \\
\text { Nitrogen } \\
\text { scheduling, } \\
\text { Summer rice, } \\
\text { Harvest index (\%) } \\
\text { and yield }\end{array}$ \\
\hline Article Info \\
\hline $\begin{array}{l}\text { Accepted: } \\
10 \text { September } 2019 \\
\text { Available Online: } \\
10 \text { October } 2019\end{array}$ \\
\hline
\end{tabular}

\section{A B S T R A C T}

\section{Introduction}

Rice (Oryza sativa L.) is stable food for millions of people in Asia pacific region. Ninety per cent of world's rice is grown and consumed in Asia. Chhattisgarh state is popularly known as "Rice bowl of India", which constitutes over $85 \%$ of the total food grain production in state. In khaif, rice is cultivated over an area of $3.68 \mathrm{~m}$ ha with productivity of $20.20 \mathrm{q} \mathrm{ha}^{-1}$. In summer season, it is cultivated in 1.97 lakh ha area 
with productivity of $38.47 \mathrm{q} \mathrm{ha}^{-1}$ (Anonymous, 2015). Imbalanced nutrient management and decreased soil organic matter are the key responsible factors for the observed declining trend in rice-based cropping systems (Nambiar 1995; Reddy and Krishnaiah 1999). Field burning of straw is often the most cost effective technique for quick disposal of straw by the rice farmers. While burning, some nutrients like carbon and nitrogen are released and not returned to the field (Bakker et al., 2013). Atmospheric pollutant emission, loss of nutrients, diminished soil biota, and reduced total $\mathrm{N}$ and $\mathrm{C}$ in the top soil layer are the major problems of rice straw burning. Hence, to avoid the soil nutrient losses and atmospheric pollution, in-situ incorporation of straw is the best option. In field after harvest rice straw have lower decomposition rate due to its higher $\mathrm{C}$ : $\mathrm{N}$ ratio (33) compared to cow dung and dhaincha (Chowdhury et al., 2002) To overcome these problems, combine harvested paddy straw is incorporated along with additional $\mathrm{N}$ source, bio-mineralizer, cow dung slurry and its combinations to know the soil nutrient availability of succeeding rice crop field.

Management of crop residues has significant implications for soil physical and chemical properties and when handled correctly, they improve soil organic matter dynamics and nutrient cycling, thereby creating a most efficient system (Smith et al., 1992). Although rice straw have several nutrient, such as 0.38 $1.01 \% \mathrm{~N}, 0.01-0.12 \% \mathrm{P}$ and $1.0-3.0 \% \mathrm{~K}$ (Ponnamperuma, 1984), they are known to produce phyto-toxic substances during their decomposition (Elliott et al., 1981). To alleviate such problems, the rice straw materials under intensive decomposition in heap or pits with adequate moisture and suitable microbial inoculants could be used as organic manure (Gaur et al., 1990) in rice field. Nitrogen scheduling/management is essential for rice cultivation as the nitrogen use efficiency is between the range of 40 to 60 percent, application of appropriate quantity of nitrogen at right time is perhaps the simplest agronomic solution for improving the use efficiency of nitrogen (Devi et al., 2012). The scientific information on option for nitrogen management in rice cultivation needs to be workout for higher productivity and reducing nitrogen demand, which will be helpful to lower the cost of cultivation. The nitrogen is most limiting factors in rice production.

\section{Materials and Methods}

In order to performance of rice straw management and nitrogen scheduling on yield and growth parameter of summer rice in Chhattisgarh plain. A replicated field experiment was conducted during summer season of 2013-14 and 2014-15 at Instructional cum Research Farm, Indira Gandhi Krishi Vishwavidyalay, Raipur (C.G.). The soil of the experimental area was 'Vertisols' which is locally known as 'Kanhar'. The soil was neutral in reaction and medium in fertility levels having low in $\mathrm{N}$, medium in $\mathrm{P}$ and high in $\mathrm{K}$. The experiment was laid out in strip plot design with three replications.

The treatments consisted of 4 rice straw management viz. burning of rice residue $\left(T_{1}\right)$, incorporation of rice straw $5 \mathrm{t} \mathrm{ha}^{-1}$ by disc harrowing twice fb irrigation at $30 \mathrm{DBT}\left(\mathrm{T}_{2}\right)$, incorporation of rice straw $5 \mathrm{t} \mathrm{ha}^{-1}$ by $\mathrm{MB}$ plough once + disc harrowing twice $\mathrm{fb}$ irrigation at 30 DBT $\left(\mathrm{T}_{3}\right)$ and normal transplanting $\left(\mathrm{T}_{4}\right)$ and 4 nitrogen scheduling viz., $40 \% \mathrm{~B}+25 \% \mathrm{AT}+25 \% \mathrm{PI}+10 \% \mathrm{~F}$ $\left(\mathrm{N}_{1}\right), 30 \% \mathrm{~B}+10 \% 15 \mathrm{DAT}+30 \% \mathrm{AT}+30 \%$ PI $\left(\mathrm{N}_{2}\right), 20 \% \mathrm{~B}+20 \% 15 \mathrm{DAT}+30 \% \mathrm{AT}+$ $30 \% \mathrm{PI}\left(\mathrm{N}_{3}\right)$ and $10 \% \mathrm{~B}+20 \% 15 \mathrm{DAT}+30 \%$ $\mathrm{AT}+30 \% \mathrm{PI}+10 \% \mathrm{~F}\left(\mathrm{~N}_{4}\right)$. Rice cultivar MTU 1010 was transplanted on $31^{\text {st }}$ January 2014 and $1^{\text {st }}$ February 2015 and harvest in $3^{\text {rd }}$ week of May in 2014 and 2015. 


\section{Results and Discussion}

\section{Growth parameters}

The two year mean data presented in Table 1 revealed that treatment incorporation of rice straw $5 \mathrm{t} \mathrm{ha}^{-1}$ by $\mathrm{MB}$ plough once + disc harrowing twice fb irrigation at $30 \mathrm{DBT}\left(\mathrm{T}_{3}\right)$ observed significantly higher plant height as compared to others treatment, and regarding rice straw management in number of tillers, dry matter accumulation and number of leaves hill $^{-1}$ was recorded significantly higher under treatment incorporation of rice straw $5 \mathrm{t}$ $\mathrm{ha}^{-1}$ by MB plough once + disc harrowing twice fb irrigation at 30 DBT $\left(\mathrm{T}_{3}\right)$ as compared to others, but it remained at par to treatments incorporation of rice straw $5 \mathrm{t} \mathrm{ha}^{-1}$ by + disc harrowing twice fb irrigation at 30 DBT $\left(\mathrm{T}_{2}\right)$ and normal transplanting $\left(\mathrm{T}_{4}\right)$. As revealed treatment incorporation of rice straw
$5 \mathrm{tha}^{-1}$ by MB plough once + disc harrowing twice fb irrigation at $30 \mathrm{DBT}\left(\mathrm{T}_{3}\right)$ registered significantly higher LAI than others, it was at par to treatment incorporation of rice straw $5 \mathrm{t}$ $\mathrm{ha}^{-1}$ by + disc harrowing twice $\mathrm{fb}$ irrigation at $30 \mathrm{DBT}\left(\mathrm{T}_{2}\right)$ on two year mean basis.

As regards to nitrogen scheduling significantly plant height and number of tillers was observed under treatment $20 \% \mathrm{~B}$ $+20 \% 15 \mathrm{DAT}+30 \% \mathrm{AT}+30 \% \mathrm{PI}\left(\mathrm{N}_{3}\right)$ as compared to others and the lower value of treatment was $40 \% \mathrm{~B}+25 \% \mathrm{AT}+25 \% \mathrm{PI}+$ $10 \% \mathrm{~F}\left(\mathrm{~N}_{1}\right)$ and the treatment $20 \% \mathrm{~B}+20 \%$ $15 \mathrm{DAT}+30 \% \mathrm{AT}+30 \% \mathrm{PI}\left(\mathrm{N}_{3}\right)$ registered significantly higher dry matter accumulation, number of leaves hill ${ }^{-1}$ and LAI, but it was at par to treatments $10 \% \mathrm{~B}+20 \% 15 \mathrm{DAT}+$ $30 \% \mathrm{AT}+30 \% \mathrm{PI}+10 \% \mathrm{~F}\left(\mathrm{~N}_{4}\right)$ on two year mean basis.

Table.1 Growth parameters of summer rice as influenced by rice straw management and nitrogen scheduling on year two mean data

\begin{tabular}{|c|c|c|c|c|c|}
\hline \multirow[t]{2}{*}{ Treatment } & $\begin{array}{l}\text { Plant height } \\
\text { (cm) }\end{array}$ & $\begin{array}{c}\text { Number of tillers } \\
\mathbf{m}^{-2}\end{array}$ & $\begin{array}{c}\text { Dry matter } \\
\text { accumulation }\left(\mathrm{g} \mathrm{m}^{-2}\right)\end{array}$ & $\begin{array}{c}\text { Number of leaves } \\
\text { hill }^{-1}\end{array}$ & $\begin{array}{l}\text { Leaf area index } \\
\text { (LAI) }\end{array}$ \\
\hline & At harvest & At harvest & At harvest & At harvest & 90 DAT \\
\hline \multicolumn{6}{|c|}{ Rice straw management } \\
\hline$T_{1}$ & 86.22 & 627.33 & 2160.63 & 27.76 & 5.81 \\
\hline $\mathbf{T}_{2}$ & 90.68 & 667.47 & 2392.28 & 33.14 & 6.14 \\
\hline$T_{3}$ & 93.63 & 680.73 & 2471.18 & 35.48 & 6.21 \\
\hline$T_{4}$ & 87.58 & 668.85 & 2356.28 & 34.30 & 6.08 \\
\hline SEm \pm & 0.84 & 7.97 & 39.75 & 1.13 & 0.02 \\
\hline $\mathrm{CD}(\mathbf{P}=\mathbf{0 . 0 5})$ & 2.89 & 27.59 & 137.55 & 3.91 & 0.07 \\
\hline \multicolumn{6}{|c|}{ Nitrogen scheduling } \\
\hline$N_{1}$ & 85.84 & 623.27 & 2032.80 & 25.51 & 5.40 \\
\hline $\mathbf{N}_{2}$ & 87.63 & 659.18 & 2393.33 & 30.15 & 5.95 \\
\hline $\mathbf{N}_{3}$ & 94.80 & 696.82 & 2534.38 & 38.23 & 6.50 \\
\hline $\mathbf{N}_{4}$ & 89.84 & 665.11 & 2419.86 & 36.79 & 6.39 \\
\hline SEm \pm & 0.52 & 7.15 & 35.20 & 0.48 & 0.04 \\
\hline $\mathrm{CD}(\mathrm{P}=\mathbf{0 . 0 5})$ & 1.80 & 24.74 & 121.80 & 1.66 & 0.14 \\
\hline
\end{tabular}


Table.2 Grain yield, straw yield and harvest index (\%) of summer rice as influenced by rice straw management and nitrogen scheduling on year two mean data

\begin{tabular}{|c|c|c|c|}
\hline Treatment & Grain yield $\left(q\right.$ ha $\left.^{-1}\right)$ & Straw yield $\left(q\right.$ ha $\left.^{-1}\right)$ & Harvest index (\%) \\
\hline \multicolumn{4}{|c|}{ Rice straw management } \\
\hline $\mathbf{T}_{1}$ & 46.22 & 55.75 & 45.34 \\
\hline $\mathbf{T}_{2}$ & 48.81 & 59.18 & 45.16 \\
\hline $\mathbf{T}_{3}$ & 50.41 & 60.26 & 45.50 \\
\hline $\mathbf{T}_{4}$ & 47.05 & 56.72 & 45.32 \\
\hline SEm \pm & 0.77 & 0.70 & 0.29 \\
\hline $\mathrm{CD}(\mathrm{P}=0.05)$ & 2.66 & 2.41 & NS \\
\hline \multicolumn{4}{|c|}{ Nitrogen scheduling } \\
\hline $\mathbf{N}_{1}$ & 45.76 & 57.68 & 44.24 \\
\hline $\mathrm{N}_{2}$ & 46.58 & 55.97 & 45.41 \\
\hline $\mathbf{N}_{3}$ & 50.71 & 59.48 & 45.99 \\
\hline $\mathbf{N}_{4}$ & 49.44 & 58.79 & 45.67 \\
\hline SEm \pm & 1.04 & 0.70 & 0.25 \\
\hline $\mathrm{CD}(\mathrm{P}=0.05)$ & 3.61 & 2.41 & 0.85 \\
\hline
\end{tabular}

\section{Grain and straw yield}

The two year mean data presented in Table 2 revealed that treatment incorporation of rice straw $5 \mathrm{t} \mathrm{ha}^{-1}$ by $\mathrm{MB}$ plough once + disc harrowing twice fb irrigation at $30 \mathrm{DBT}\left(\mathrm{T}_{3}\right)$ registered significantly higher grain and straw yield as compared to others, but it was at par to treatment incorporation of rice straw $5 \mathrm{t} \mathrm{ha}$ ${ }^{1}$ by + disc harrowing twice $\mathrm{fb}$ irrigation at 30 DBT $\left(T_{2}\right)$ on two years mean basis. This might be due to straw incorporation which saved considerable amounts of nitrogen, phosphorus, potassium and sulphur and organic matter which would otherwise lost by burning. This is in accordance with the finding of (Singh et al., 2008). The harvest index did not differ significantly due to different rice straw management treatments on two year mean basis. Among nitrogen scheduling, treatment $20 \% \mathrm{~B}+20 \% 15$ DAT $+30 \%$ AT $+30 \%$ PI $\left(\mathrm{N}_{3}\right)$ recorded significantly higher grain and straw yield as compared to others, but it was at par to $10 \% \mathrm{~B}$
$+20 \% 15 \mathrm{DAT}+30 \% \mathrm{AT}+30 \% \mathrm{PI}+10 \% \mathrm{~F}$ $\left(\mathrm{N}_{4}\right)$. In harvest index was recorded significantly highest under treatment $20 \% \mathrm{~B}$ $+20 \% 15$ DAT $+30 \%$ AT $+30 \%$ PI $\left(\mathrm{N}_{3}\right)$ which was at par to treatment $30 \% \mathrm{~B}+10 \%$ $15 \mathrm{DAT}+30 \% \mathrm{AT}+30 \% \mathrm{PI}\left(\mathrm{N}_{2}\right)$ and $10 \% \mathrm{~B}$ $+20 \% 15 \mathrm{DAT}+30 \% \mathrm{AT}+30 \% \mathrm{PI}+10 \% \mathrm{~F}$ $\left(\mathrm{N}_{4}\right)$ on mean basis. The higher yields in above treatments are the resultant of higher yield attributes recorded in these treatments. Similar results were reported by (Sharma and Agrawal, 2006). The lowest grain and straw yield was recorded under $40 \% \mathrm{~B}+25 \% \mathrm{AT}+$ $25 \% \mathrm{PI}+10 \% \mathrm{~F}\left(\mathrm{~N}_{1}\right)$ treatment which might be due to the fact that major share of $\mathrm{N}$ were applied during the early growth stages, produced lower grain yield. This may be attributed to the failure to synchronize the $\mathrm{N}$ supply as per demand of the crop at all the major system of crop growth crucial for higher yields (Chaudhary et al., 2013). Delayed application of $\mathrm{N}$ might be helpful in keeping the plant greener for long and thereby facilitating the higher production and 
translocation of photosynthetic towards economic parts (Dar et al., 2000).

\section{References}

Anonymous, 2015. Report of Agriculture Department, Chhattisgarh Government Krishi Diary, Director of Extension Services, IGKV, Raipur.

Devi, M.G., Reddy, S.T., Sumathi V., Pratima, T. and John, K. 2012. Nitrogen management to improve the nutrient uptke, yield and quality parameters of scented rice under aerobic culture. International Journal of Applied Biology and Pharmaceutical Technology, 3(1): 340-344.

Elliott, L., Cochran, V.L. and Papendick, R.I. 1981. Wheat residues and nitrogen placement effects on wheat growth in green house. Soil. Sci. 131: 48-52.

Kumari, P., Mishra, G. C., Pant, A. K., Shukla, G. and Kujur, S. N. 2014. Comparison of forecasting ability of different statistical models for productivity of rice (Oryza sativa L.) in India. The Ecoscan. 8 (3 \& 4): 193-198.

Nambiar K.K.M. 1995. Major cropping systems in India. In: Barnett B., Payne R. and Steiner R. (eds), Agricultural Sustainability: Economic, Environmental And Statistical Considerations. John Wiley \& Sons, New York, pp. 133-169.

Sharma, P. and Agrawal, A. 2006. Effect of different level of nitrogen fertilizer application on yield, yield attributes and chlorophyll in two rice varieties. Vegetos 19 (1):101-106.

Singh, R.P., Dhaliwal, H.S., Humphreys, E., Sindhu, H.S., Singh, M., Singh Y. and Blackwell, J. 2008. Economic assessment of the happy seeder for ricewheat systems in Punjab, India, AARES 52nd Annual Conference, Canberra, ACT, Australia.

Smith J.L., Papendick R.I., Bezicek D.F. and Lynch J.M. 1992. Soil organic matter dynamics and crop residue management. In Blaine Metting F. Jr. (ed.), Soil Microbial Ecology: Applications in Agricultural and Environmental Management. Marcel Dekker, New York, pp. 65-94.

Bakker R, Elbersen W, Poppens R, Lesschen J.P., Rice straw and wheat straw. Potential feed stocks for the Biobased Economy. NL Agency Ministry of Economic Affairs, Netherland. 2013, 31.

Chowdhury M.A.H, Begum R, Kabir M.R., Zakir H.M. Plant and animal residue decomposition and transformation of $\mathrm{S}$ and $\mathrm{P}$ in soil. Pak. J. Bio. Sci. 2002; 5(7):736-739.

Reddy, M. N. and Krishnaiah, K. 1999. Current status of crop response to fertilizers in different agro-climatic regions- Experience of the all India Coordinated Rice Improvement Project. Fertilizer News 44:113-126.

\section{How to cite this article:}

Banjara, G.P., D.K. Chandrakar and Birendra Tigga. 2019. Performance of Rice Straw Management and Nitrogen Scheduling on Yield and Growth Parameters of Summer Rice in Chhattisgarh Plain. Int.J.Curr.Microbiol.App.Sci. 8(10): 1079-1083.

doi: https://doi.org/10.20546/ijcmas.2019.810.127 